ISSN 2075-4701

www.mdpi.com/journal/metals/

Article

\title{
Method of Preventing Shrinkage of Aluminum Foam Using Carbonates
}

\author{
Takuya Koizumi ${ }^{1, *}$, Kota Kido ${ }^{1}$, Kazuhiko Kita ${ }^{1}$, Koichi Mikado ${ }^{2}$, Svyatoslav Gnyloskurenko ${ }^{3,4}$ \\ and Takashi Nakamura ${ }^{3}$
}

1 Machinery and Engineering Group, YKK Corporation, Yoshida Kurobe City, Toyama 938-8601, Japan; E-Mails: k-kido@ykk.co.jp (K.K.); k-kita@ykk.co.jp (K.K.)

2 Fastening Products Group, YKK Corporation, Yoshida Kurobe City, Toyama 938-8601, Japan; E-Mail: k-mikado@ykk.co.jp

3 Institute of Multidisciplinary Research for Advanced Materials, Tohoku University, Sendai 980-8577, Japan; E-Mails: slavgn@yahoo.com (S.G.); ntakashi@sda.att.ne.jp (T.N.)

4 Physical-Technological Institute of Metals and Alloys, The National Academy of Sciences of Ukraine, Kiev 04004, Ukraine

* Author to whom correspondence should be addressed; E-Mail: t-koizumi@ykk.co.jp; Tel.: +81-765-54-8345; Fax: +81-765-84-8818.

Received: 23 September 2011; in revised form: 7 December 2011 / Accepted: 15 December 2011 / Published: 23 December 2011

\begin{abstract}
Metallic foams are commonly produced using titanium hydride as a foaming agent. Carbonates produce aluminum foam with a fine and homogenous cell structure. However, foams produced using carbonates show marked shrinkage, which is clearly different from those produced using titanium hydride. It is essential for practical applications to clarify foam shrinkage and establish a method of preventing it. In this research, cell structures were observed to study the shrinkage of aluminum foam produced using carbonates. The cells of foam produced using dolomite as a foaming agent connected to each other with maximum expansion. It was estimated that foaming gas was released through connected cells to the outside. It was assumed that cell formation at different sites is effective in preventing shrinkage induced by cell connection. The multiple additions of dolomite and magnesium carbonate, which have different decomposition temperatures, were applied. The foam in the case with multiple additions maintained a density of 0.66 up to $973 \mathrm{~K}$, at which the foam produced using dolomite shrank. It was verified that the multiple additions of carbonates are effective in preventing shrinkage.
\end{abstract}


Keywords: aluminum foam; carbonates; shrinkage

\section{Introduction}

Metallic foams have unique properties, such as low density, good energy-absorbing capability, and low thermal conductivity. One of the manufacturing methods for metallic foams is the Fraunhofer method. This method uses a typical powder metallurgy (PM) route [1] that entails the hot extrusion of an aluminum matrix powder and a $\mathrm{TiH}_{2}$ to make precursor, the resulting product of which is then heated in a closed die to produce foam for near-net shaping. $\mathrm{TiH}_{2}$ is a popular foaming agent because of its decomposition temperature, which is close to the melting temperature of aluminum alloys. However, $\mathrm{TiH}_{2}$ is expensive.

One of the authors presented carbonates as alternatives to $\mathrm{TiH}_{2}$ [2], because they are inexpensive. Calcium carbonate gives a finer cell structure than $\mathrm{TiH}_{2}$ in the melt route. It also induces $\mathrm{CO}_{2}$ gas, which oxidizes and stabilizes the aluminum cell surface. Thus, aluminum foam produced using carbonates has a finer cell structure than that produced using $\mathrm{TiH}_{2}$. The effect of oxide layer on foam stabilization has been reported from other researchers [3-5]. On the other hand, foam by $\mathrm{TiH}_{2}$ are stabilized by solid particles, like $\mathrm{SiO}_{2}[6]$.

In the PM route, some carbonates are used as foaming agents, and their resulting foams show fine cell structure and better mechanical properties [7,8]. Still, foaming by carbonates in the PM route remains to be elucidated.

We have studied the principle of foaming by carbonates, and found that dolomite and magnesium carbonate are suitable foaming agents for AlSiCu alloy. The foams produced using dolomite and magnesium carbonate have a fine and homogenous cell structure [9-11]. The foam produced using $\mathrm{TiH}_{2}$ shows the coalescence of cells, before rupture by gravity [12,13]. On the other hand, the foam produced using carbonates shows marked shrinkage, which is clearly different from that of $\mathrm{TiH}_{2}$. The transmission images of 1.2 mass \% dolomite foam, which were obtained at specific temperatures using transmission X-ray system, are shown in Figure 1 [11]. The foam markedly shrank at $1003 \mathrm{~K}$ after maximum expansion at $973 \mathrm{~K}$. Such marked shrinkage adversely affects the near-net shaping in the PM route. Accordingly, it is essential for practical applications to clarify foam shrinkage and establish a method of preventing it.

In the present study, the cell structures during foam shrinkage and a method of preventing such shrinkage were investigated.

\section{Results and Discussion}

\subsection{Observations of Shrinkage}

The cell structures of the foam produced using dolomite were observed to clarify foam shrinkage induced by carbonate-foaming agents. The cooling temperatures and densities of the foams produced using 2.0 mass\% dolomite are shown in Figure 2(a). The foam expanded to a density of 0.88 at $943 \mathrm{~K}$. Then, it showed maximum expansion at a density of 0.60 at $958 \mathrm{~K}$. After that, it shrank to show a 
density of 1.61 at $968 \mathrm{~K}$. The foams and their cross-sectional views are shown in Figure 3. The foams at 943 and $958 \mathrm{~K}$ had spherical cell structures. The foam at $963 \mathrm{~K}$ shrank and its number of cells decreased.

Figure 1. Foams produced using 1.2 mass $\%$ dolomite observed with transmission X-ray system: (a) start; (b) $863 \mathrm{~K}$; (c) $873 \mathrm{~K}$; (d) $973 \mathrm{~K}$ and (e) $1003 \mathrm{~K}$ [11].
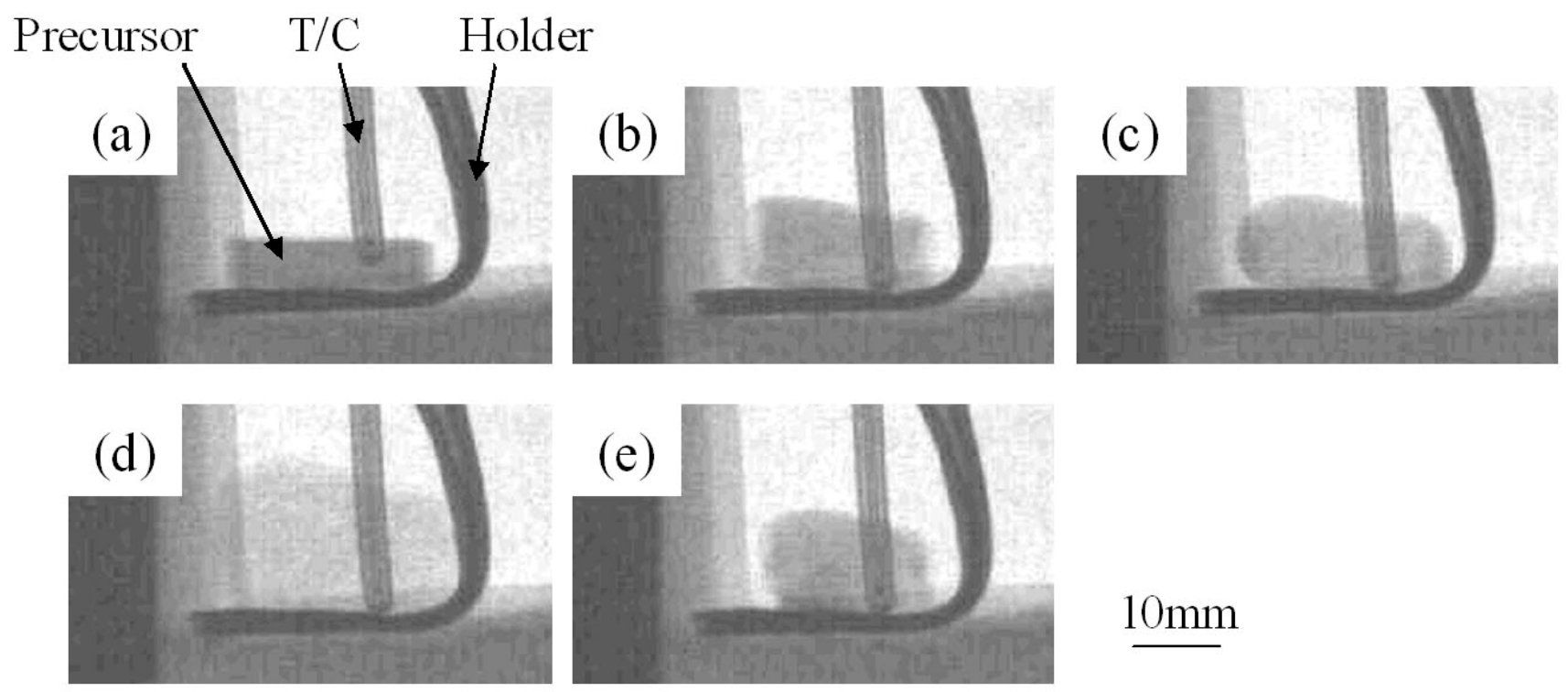

\section{$10 \mathrm{~mm}$}

Figure 2. Densities of foams: (a) 2.0 mass\% dolomite and (b) 2.0 mass $\%$ dolomite and 1.0 mass $\% \mathrm{MgCO}_{3}$.

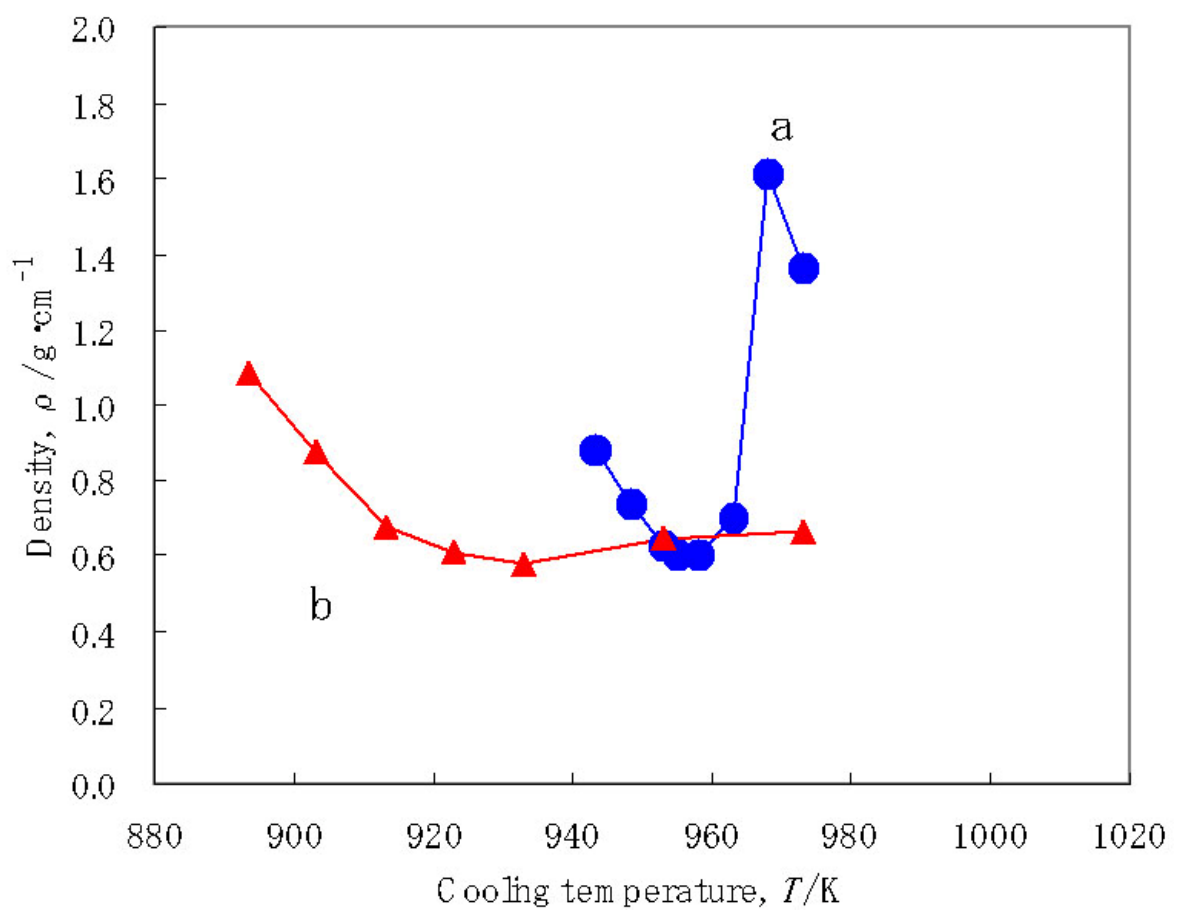


Figure 3. Foams produced using 2.0 mass $\%$ dolomite and their cross sectional views: (a) at $943 \mathrm{~K}, \rho: 0.88 \mathrm{~g} / \mathrm{cm}^{3},(\mathbf{b})$ at $958 \mathrm{~K}, \rho: 0.60 \mathrm{~g} / \mathrm{cm}^{3}$, and (c) at $968 \mathrm{~K}, \rho: 1.61 \mathrm{~g} / \mathrm{cm}^{3}$.

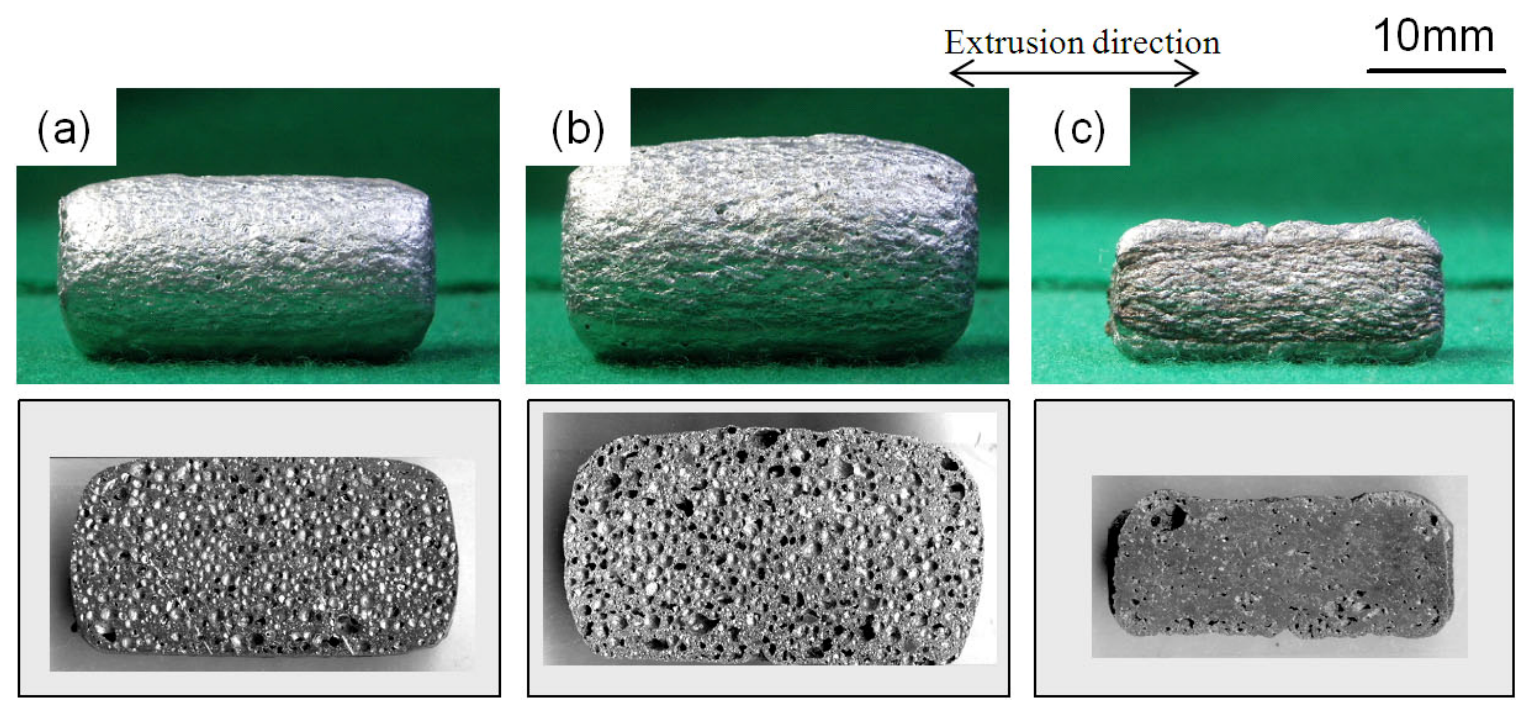

The cell structures of the foams were observed by optical microscopy, the results of which are shown in Figure 4. Two cells of different sizes were observed in the foams at 943 and $958 \mathrm{~K}$. Coarse cells about $1 \mathrm{~mm}$ in size were induced by the water vapor absorbed onto the AlSiCu powder surface during the melting of the matrix, and fine cells of about 50-70 $\mu \mathrm{m}$ in size were induced by dolomite decomposition [11]. At $943 \mathrm{~K}$, coarse cells were mainly observed. At $958 \mathrm{~K}$, the number of fine cells increased markedly. The coarse cells connected to each other through fine cells. The cells maintained their shape as an open cell structure. Foam by carbonates has the stable oxidized cell walls [2-5], which should prevent cell coalesces. At $968 \mathrm{~K}$, most of the cells disappeared.

Figure 4. Microstructures of foams produced using 2.0 mass $\%$ dolomite, lower pictures are magnified images of upper row: (a) at $943 \mathrm{~K}, \rho: 0.88 \mathrm{~g} / \mathrm{cm}^{3}$; (b) at $958 \mathrm{~K}, \rho: 0.60 \mathrm{~g} / \mathrm{cm}^{3}$ and $(\mathbf{c})$ at $968 \mathrm{~K}, \rho: 1.61 \mathrm{~g} / \mathrm{cm}^{3}$.
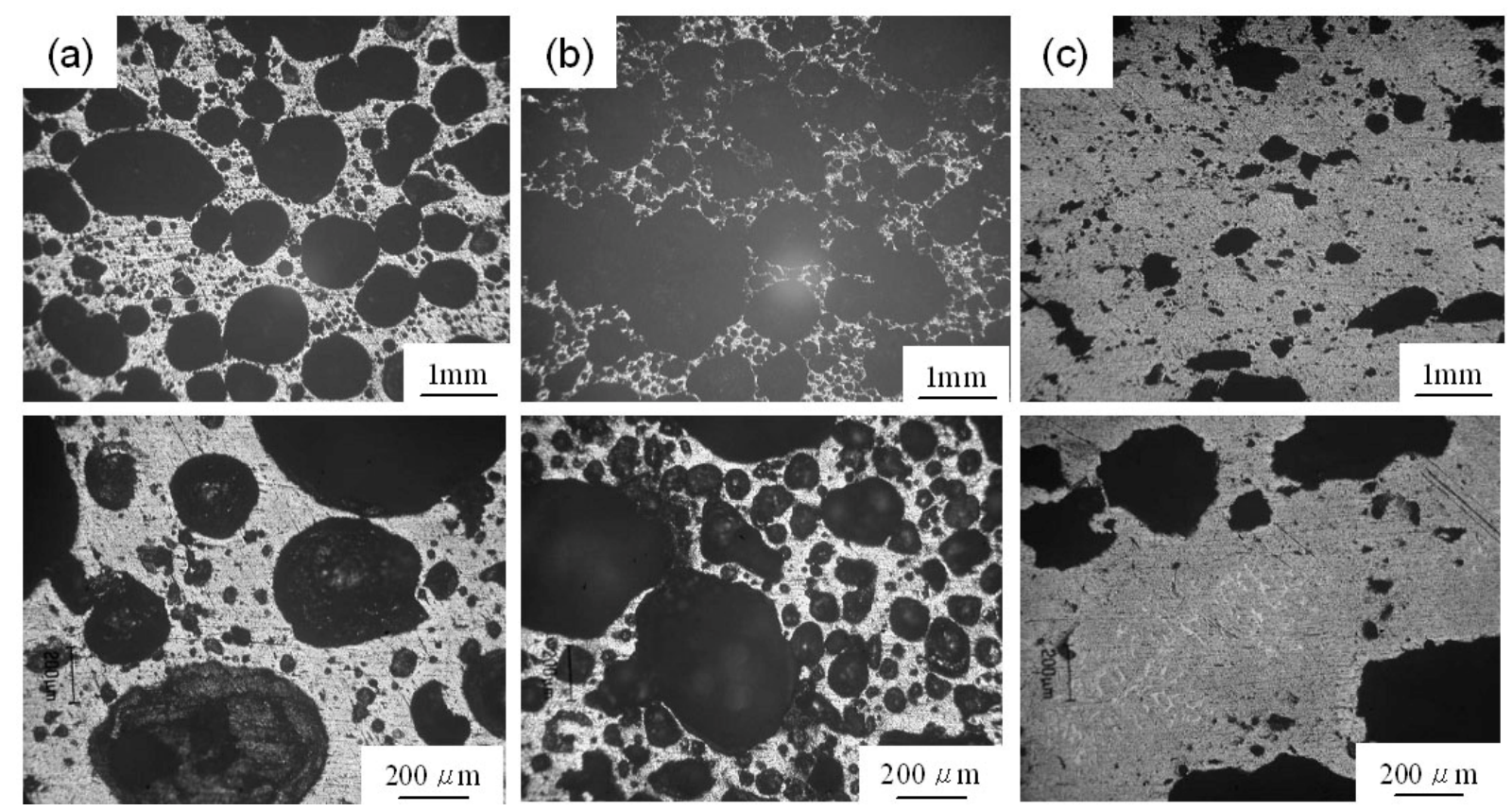
It is assumed that the shrinkage by the carbonate-foaming agent is induced by gas release through connected cells because of the change in cell structure from foaming to shrinkage. As shown in Figure 4(b), when most of the cells are connected to each other, gas can be released rapidly to the outside, namely, it can induce marked shrinkage.

\subsection{Method of Preventing Shrinkage}

A method of preventing shrinkage was studied on the basis of the hypothesis, that the stability of the oxidized cell wall is the reason for both the fine cell structure and the cell connection. It is difficult to prevent cell connection. It was assumed that cell formation at different sites is effective in preventing shrinkage, even if cell connections are formed.

Gas could be generated at new sites by adding another foaming agent that has a different decomposition temperature. The mass reduction rates of dolomite, magnesium carbonate, and calcium carbonate obtained by thermogravimetric analysis-differential thermal analysis (TG-DTA) are shown in Figure 5 [9]. Dolomite started to decompose at $773 \mathrm{~K}$ and rapidly decomposed above $1013 \mathrm{~K}$. In contrast, magnesium carbonate decomposed from 793 to $993 \mathrm{~K}$ and calcium carbonate from 993 to $1113 \mathrm{~K}$. Calcium carbonate is ineffective for multiple additions, because it does not decompose at $968 \mathrm{~K}$, at which foam produced using dolomite shrinks. In the case of multiple additions of dolomite and magnesium carbonate, the latter decomposes first, followed by the former. This creates new cell sites, which are expected to prevent shrinkage.

Figure 5. thermogravimetric (TG) curves of foaming agents: (a) dolomite; (b) $\mathrm{MgCO}_{3}$ and (c) $\mathrm{CaCO}_{3}[9]$.

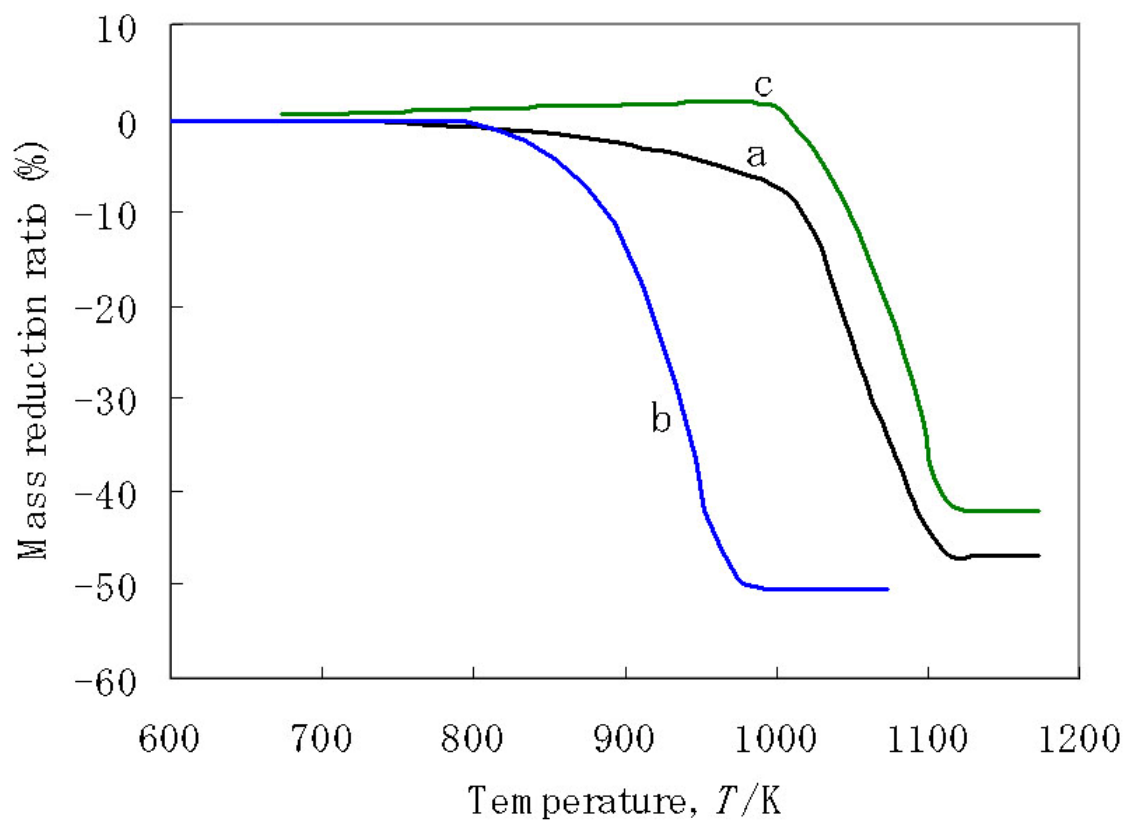

\subsection{Foaming by Multiple Additions}

Precursors with multiple additions of 2.0 mass $\%$ dolomite and 1.0 mass $\%$ magnesium carbonate were prepared. The cooling temperatures and densities of the foams produced with multiple additions are shown in Figure 2(b). The foam expanded to a density of 0.87 at $903 \mathrm{~K}$, then showed maximum 
expansion at a density of 0.58 at $933 \mathrm{~K}$. The foaming temperature for multiple additions was lower than that for dolomite, because magnesium carbonate has a lower decomposition temperature than dolomite. A density of 0.66 was maintained at $973 \mathrm{~K}$, at which the foam produced using dolomite shrank markedly. It was verified that multiple additions are effective in preventing foam shrinkage.

The foams produced using multiple additions and their cross-sectional views are shown in Figure 6. At $903 \mathrm{~K}$, they maintained a fine cell structure. At $933 \mathrm{~K}$, cracks along with extrusion direction were observed. At $973 \mathrm{~K}$, the foam showed the same shape and cell structure as that at $933 \mathrm{~K}$. Multiple additions are effective for preventing shrinkage, but have problem to keep homogenous cell structure.

The cell structures of the foams were observed by optical microscopy, the results of which are shown in Figure 7. Most of the cells were below $200 \mu \mathrm{m}$ in size, because the increased amount of foaming agents inhibits cell coarsening by water absorption. At 933 and $973 \mathrm{~K}$, two cells connected to each other showed similar structures. It is presumed that dolomite created new cells while the cells produced by magnesium carbonate connected.

Cell size distributions of foams were evaluated by image processing software, which is shown in Figure 8. In this analysis, area ratios of each cell size are shown for each foam. Foam by dolomite has bimodal cell size distribution, which peaks are $100 \mu \mathrm{m}$ and $600 \mu \mathrm{m}$. Foam by multiple additions has also bimodal cell size distribution but those peaks become closer in $200 \mu \mathrm{m}$ and $450 \mu \mathrm{m}$. Foam by multiple additions is finer and more homogenous cell structure than that by dolomite at this density.

Figure 6. Foams produced using 2.0 mass $\%$ dolomite and 1.0 mass $\% \mathrm{MgCO}_{3}$, and their cross sectional views: (a) at $903 \mathrm{~K}, \rho: 0.87 \mathrm{~g} / \mathrm{cm}^{3}$, (b) at $933 \mathrm{~K}, \rho: 0.58 \mathrm{~g} / \mathrm{cm}^{3}$, and (c) at $973 \mathrm{~K}, \rho: 0.66 \mathrm{~g} / \mathrm{cm}^{3}$.

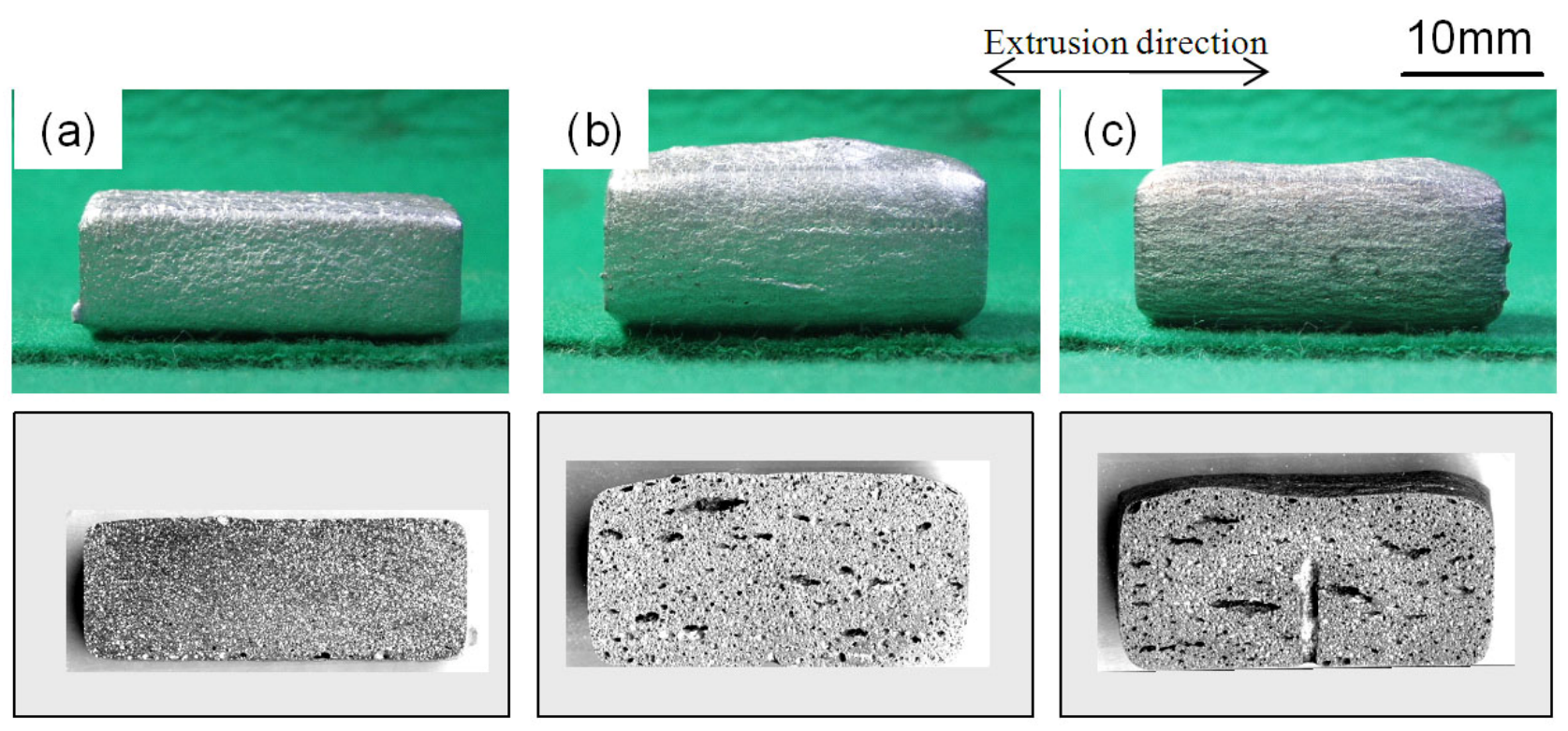


Figure 7. Microstructures of foams produced using 2.0 mass $\%$ dolomite and 1.0 mass $\%$ $\mathrm{MgCO}_{3}$, lower pictures are magnified images of upper row: (a) at $903 \mathrm{~K}, \rho: 0.87 \mathrm{~g} / \mathrm{cm}^{3}$; (b) at $933 \mathrm{~K}, \rho: 0.58 \mathrm{~g} / \mathrm{cm}^{3}$, and (c) at $973 \mathrm{~K}, \rho: 0.66 \mathrm{~g} / \mathrm{cm}^{3}$.
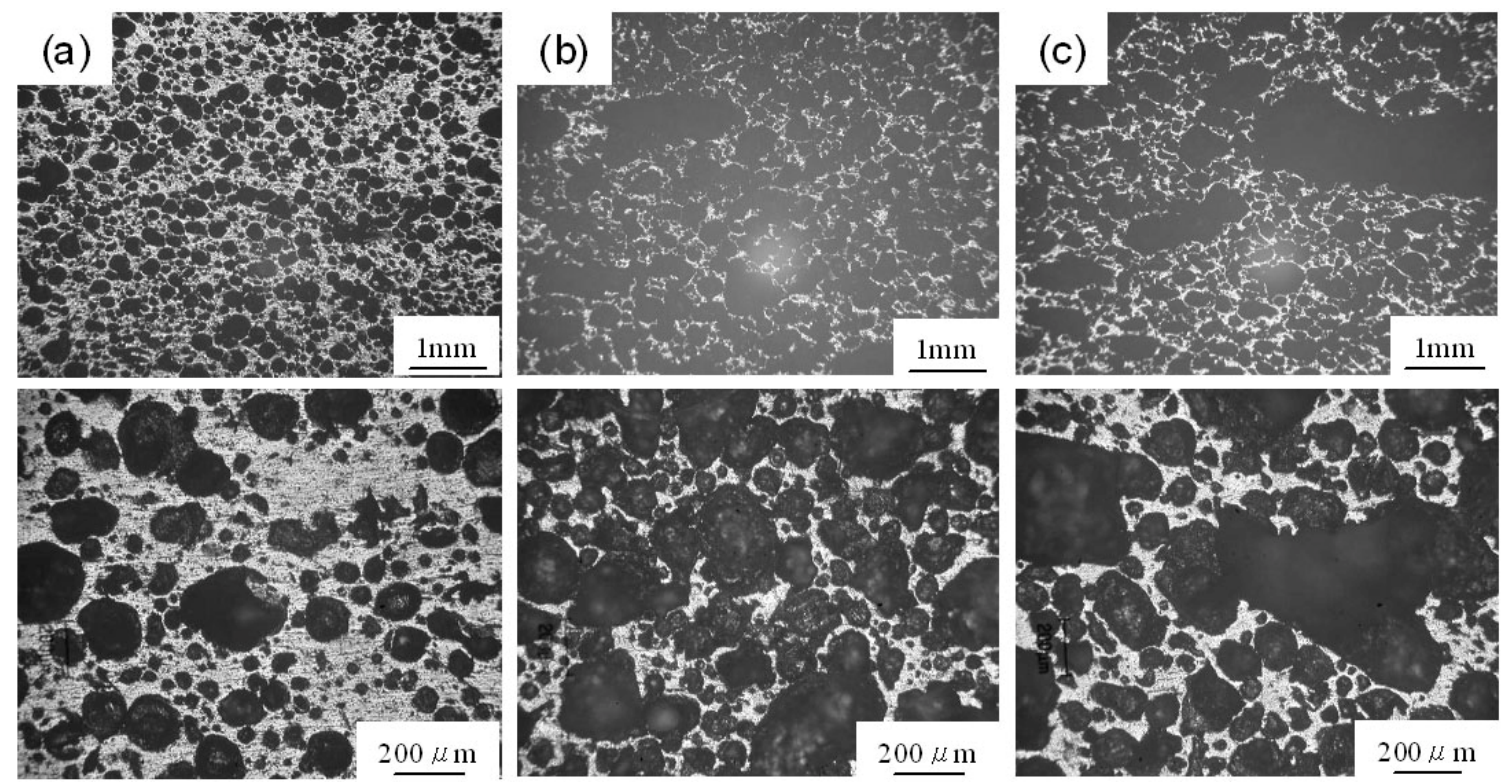

Figure 8. Cell size distributions of foam: (a) foam by dolomite, at $943 \mathrm{~K}, \rho: 0.88 \mathrm{~g} / \mathrm{cm}^{3}$; and (b) foam by multiple additions, at $903 \mathrm{~K}, \rho: 0.87 \mathrm{~g} / \mathrm{cm}^{3}$.
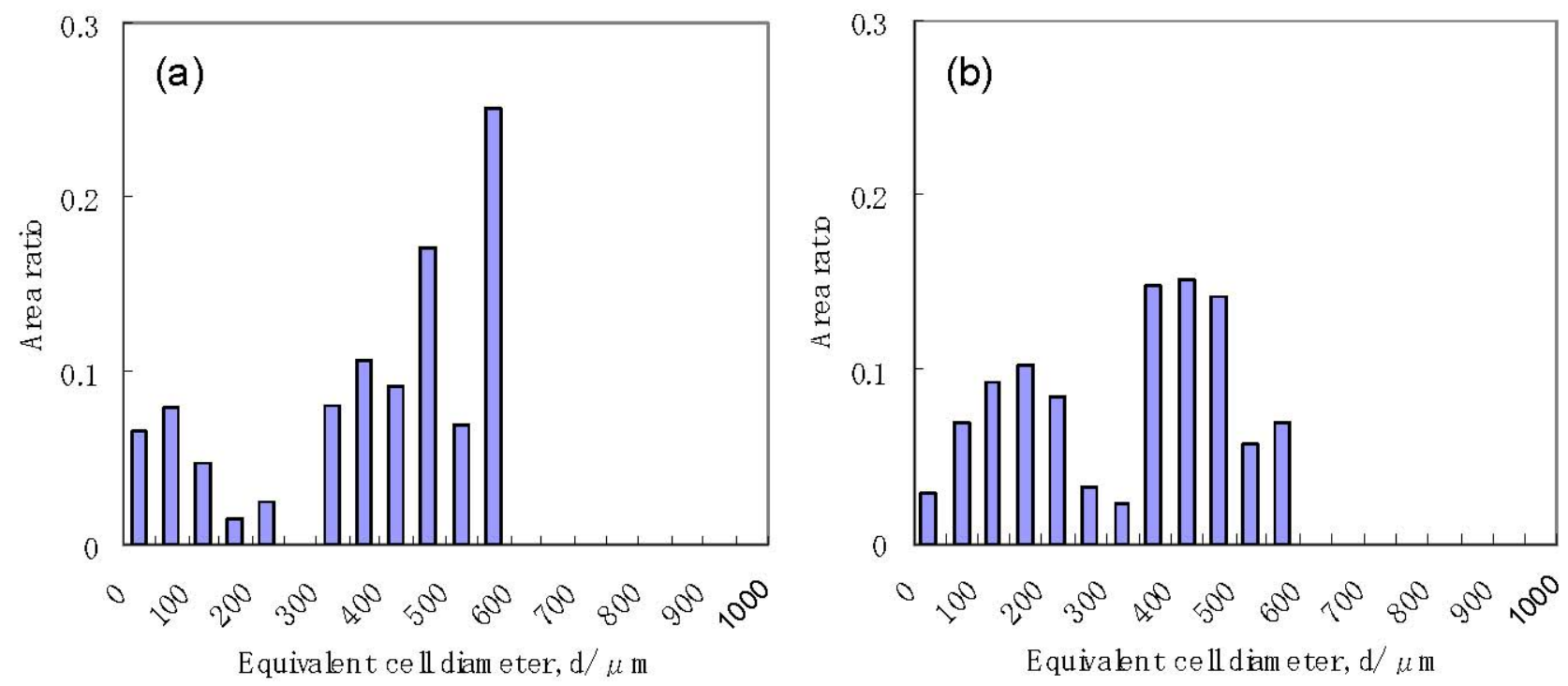

\section{Experimental}

\subsection{Precursor}

Air-atomized AlSiCu powder containing mass fractions of $\mathrm{Si}(10.8 \%)$ and $\mathrm{Cu}(2.4 \%)$ was used to prepare the precursor. The powder was sieved through a $150 \mu \mathrm{m}$ mesh before use. The dolomite $\left[\mathrm{CaMg}\left(\mathrm{CO}_{3}\right)_{2}\right]$ used was obtained from Murakashi Lime Industry Co., Ltd. and had an average particle size of $3.5 \mu \mathrm{m}$. The magnesium carbonate $\left(\mathrm{MgCO}_{3}\right)$ used had an average particle size of $9 \mu \mathrm{m}$. 
$\mathrm{AlSiCu}$ powder was mixed with the carbonates of the following amounts: (a) 2.0 mass $\%$ dolomite, (b) 2.0 mass $\%$ dolomite and 1.0 mass $\%$ magnesium carbonate. The powder mixtures were compacted at ambient temperature using a uniaxial press at $350 \mathrm{MPa}$ to obtain a relative density of more than $90 \%$. The precursors were extruded at $623 \mathrm{~K}$ using the green compact. The extrusion ratio was 29 , and the cross section of each precursor was $5.8 \mathrm{~mm}$ high and $38 \mathrm{~mm}$ wide. The cross-sectional views of precursors are shown in Figure 9. No agglomeration was observed in both precursors. Larger particle in Figure 9(b) is $\mathrm{MgCO}_{3}$.

Figure 9. Cross-sectional views of precursors: (a) 2.0 mass $\%$ dolomite, $\rho: 2.69 \mathrm{~g} / \mathrm{cm}^{3}$ and (b) 2.0 mass $\%$ dolomite and 1.0 mass $\% \mathrm{MgCO}_{3}, \rho: 2.70 \mathrm{~g} / \mathrm{cm}^{3}$.
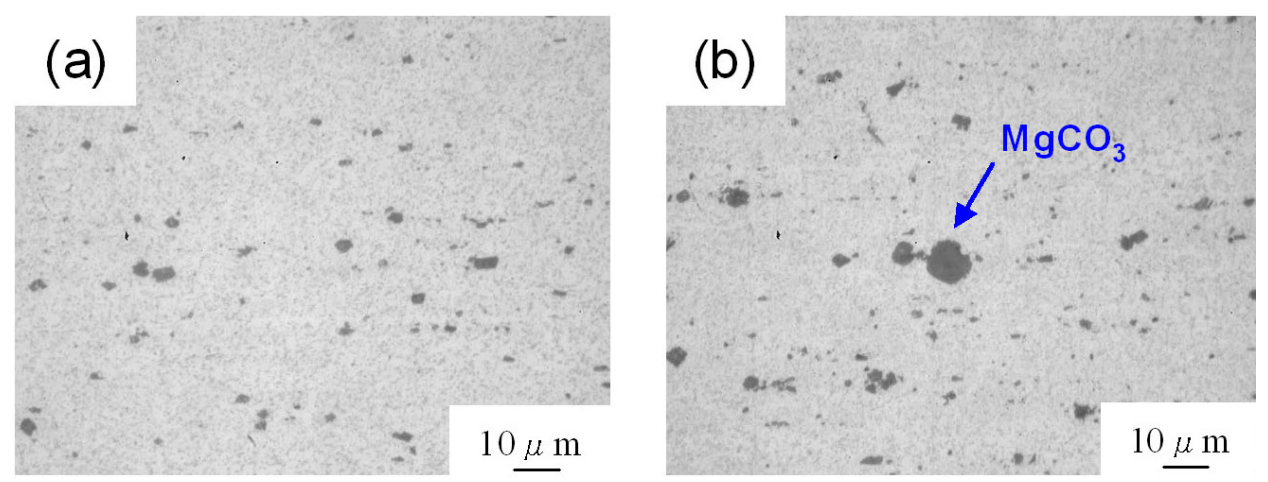

\subsection{Foaming Experiment}

The precursors were cut to a length of $30 \mathrm{~mm}$ and a width of $10 \mathrm{~mm}$ measured with a type $\mathrm{K}$ thermocouple, which is a diameter of $1.6 \mathrm{~mm}$. They were then heated to specific temperatures in a furnace kept at $1098 \mathrm{~K}$. The formed aluminum foams were cooled in air.

The density of each foam was measured using the Archimedes principle, and the cell structure of each foam was observed by optical microscopy.

\section{Conclusions}

In this study, the shrinkage of foams by carbonate and a method of preventing it were discussed.

From the observations of cell structures, it was assumed that cell formation at different sites is effective in preventing shrinkage induced by cell connections.

It was verified that multiple additions of 2.0 mass $\%$ dolomite and 1.0 mass $\%$ magnesium carbonate are effective in preventing shrinkage. Foam by multiple additions has finer cell structure at a density of 0.87 than that by single dolomite, but has problems maintaining the homogenous cell structure at a lower density.

\section{References}

1. Baumeister, J. Verfahren zur Herstellung Poroser Meallkorper. DE4018360, 8 June 1990.

2. Nakamura, T.; Gnyloskurenko, S.V.; Sakamoto, K.; Byakova, A.V.; Ishikawa, R. Development of new foaming agent for metal foam. Mater. Trans. 2002, 43, 1191-1196. 
3. Gergely, V.; Curran, D.C.; Clyne, T.W. The foamcarp process: Foaming of aluminium MMCs by the chalk-aluminium reaction in precursors. Compos. Sci. Technol. 2003, 63, 2301-2310.

4. Papadopoulos, D.P.; Omar, H.; Stergioudi, F.; Tsipas, S.A.; Lefakis, H.; Michailidis, N.J. A novel method for producing Al-foams and evaluation of their compression behavior. J. Porous Mater. 2010, 17, 773-777.

5. Papadopoulos, D.P.; Omar, H.; Stergioudi, F.; Tsipas, S.A.; Michailidis, N. The use of dolomite as foaming agent and its effect on the microstructure of aluminium metal foams-comparison to titanium hydride. Colloids Surf. A 2011, 382, 118-123.

6. Ip, S.W.; Wang, Y.; Toguri, J. Aluminum foam stabilization by solid particles. Can. Metall. Quart. 1999, 38, 81-92.

7. Cambronero, L.E.G.; Ruiz-Roman, J.M.; Corpas, F.A.; Ruiz Prieto, J.M. Manufacturing of Al-Mg-Si alloy foam using calcium carbonate as foaming agent. J. Mater. Process. Technol. 2009, 209, 1803-1809.

8. Haesche, M.; Lehmhus, D.; Weise, J.; Wichmann, M.; Mocellin, I.C.M. Carbonates as foaming agent in chip-based aluminium foam precursor. J. Mater. Sci. Technol. 2010, 26, 845-850.

9. Koizumi, T.; Kido, K.; Kita, K.; Mikado, K.; Gnyloskurenko, S.V.; Nakamura, T. Foaming agents for powder metallurgy production of aluminum foam. Mater. Trans. 2011, 52, 728-733.

10. Koizumi, T.; Kido, K.; Kita, K.; Mikado, K.; Gnyloskurenko, S.V.; Nakamura, T. The improvement of mechanical properties of metallic foams by carbonates as a foaming agent. J. Jpn. Inst. Metals 2011, 75, 355-360.

11. Koizumi, T.; Kido, K.; Kita, K.; Mikado, K.; Gnyloskurenko, S.V.; Nakamura, T. Effect of mass fraction of dolomite on the foaming behavior of Al foam by PM route. Metallur. Trans. A 2011, submitted for publication.

12. Duarte, I.; Banhart, J. A study of aluminium foam formation-kinetics and microstructure. Acta Mater. 2000, 48, 2349-2362.

13. Banhart, J. Metal foams: Production and stability. Adv. Eng. Mater. 2006, 8, 781-794.

(C) 2012 by the authors; licensee MDPI, Basel, Switzerland. This article is an open access article distributed under the terms and conditions of the Creative Commons Attribution license (http://creativecommons.org/licenses/by/3.0/). 